\title{
Search for an artificially buried karst cave entrance using ground penetrating radar: a successful case of locating the S-19 Cave in the Mt. Kanin massif (NW Slovenia)
}

\author{
Andrej Gosar ${ }^{1,2^{*}}$ and Teja Čeru ${ }^{1}$ \\ ${ }^{1}$ University of Ljubljana, Faculty of Natural Sciences and Engineering, Aškerčeva c. 12, SI-1000 Ljubljana, Slovenia \\ ${ }^{2}$ Slovenian Environment Agency, Seismology and Geology Office, Vojkova 1b, SI-1000 Ljubljana, Slovenia
}

\begin{abstract}
The S-19 Cave was with its explored depth of $177 \mathrm{~m}$ one of the most important caves of the Mt. Kanin massif, but after its discovery in 1974, a huge snow avalanche protection dyke was constructed across the cave entrance. To excavate the buried cave, the accurate location of the cave had to be determined first. Since the entrance coordinates were incorrect and no markers were available, application of geophysical techniques was necessary to do this. A Ground Penetrating Radar (GPR) with special $50 \mathrm{MHz}$ rough terrain antennas was selected as the single suitable geophysical method for the given conditions where thick debris overlay a rugged limestone surface. Nevertheless, it was not possible to directly detect the relatively narrow cave entrance itself due to data resolution limits. However, a historical photo of the area showed that the cave entrance was located in a local depression, which therefore represented the main target of the GPR survey. Seven GPR profiles were measured across the rough and steep surface causing difficulties in traversing the area with sensitive research equipment. In all recorded radargrams a small depression was clearly imaged under debris, and recognized as a topographic feature with the cave entrance. Based on the GPR data interpretation, the exact location for digging was determined and the thickness of debris assessed at $6.5-7 \mathrm{~m}$. A massive excavation by a dredger resulted in a successful opening of the cave entrance, confirming both its geophysically determined location and its estimated depth. The application of an advanced geophysical method was therefore proven successful in providing a solution to this specific case in karst exploration and an important cave was saved.
\end{abstract}

Keywords: $\quad$ ground penetrating radar, speleology, cavity detection, Mt. Kanin massif, S-19 Cave

Received 1 February 2016; Revised 25 April 2016; Accepted 25 April 2016

Citation: Gosar A. and Čeru T., 2016. Search for an artificially buried karst cave entrance using ground penetrating radar: a successful case of locating the S-19 Cave in the Mt. Kanin massif (NW Slovenia). International Journal of Speleology, 45 (2), 135-147. Tampa, FL (USA) ISSN 0392-6672 http://dx.doi.org/10.5038/1827-806X.45.2.1979

\section{INTRODUCTION}

The Kanin massif is speleologically one of the most important high-mountain karst areas in Europe. It is located at the border between Slovenia and Italy (Fig. 1) and is built of more than $1000 \mathrm{~m}$ thick Upper Triassic Dachstein limestone. The potential for very deep caves is significant and five caves deeper than $1000 \mathrm{~m}$ have been explored so far (Gabrovšek \& Otoničar, 2010). The total number of explored caves is above one thousand and each year tens of new caves are registered (Čekada et al., 2011).

The speleological explorations of the Kanin massif started in the 1960s at the lower part of the Kanin plateau, but only a few deeper caves were found (Pirnat, 2002). In 1974 a cable-car was constructed to the Kanin plateau (Kunaver et al., 2011), which improved the capabilities for cave exploration. However, the fate of the S-19 Cave, which is located in the vicinity of one of its intermediate stations (Figs. 1 and 4), is connected to the construction of this cable-car. This cave was explored in 1974 to the depth of $177 \mathrm{~m}$ with open continuation and was the deepest explored so far (Pirnat, 2002). But due to a big snow avalanche, which damaged the cable-car station during the next winter, a huge protection dyke was later built across the cave. It was a great drawback for speleologists that the access to one of the most promising caves in the area was lost.

Renovation activities of the Kanin cable-car started in 2015 and first a new access road was constructed in the vicinity of the buried S-19 Cave. It seemed that this was a unique opportunity to re-open the cave entrance for further exploration by a dredger 


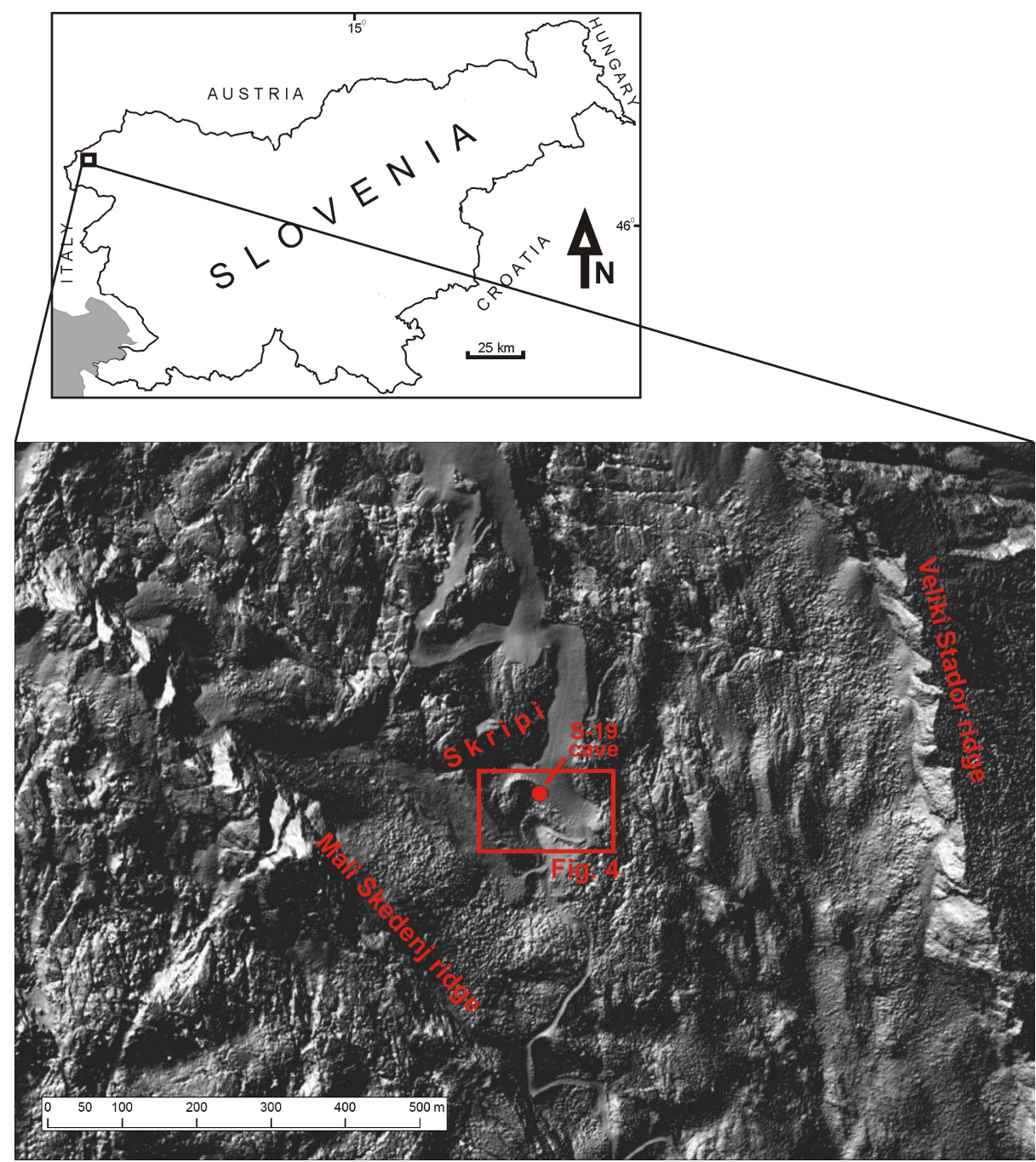

Fig. 1. Location of the study area and S-19 Cave in the Kanin massif shown on $1 \mathrm{~m}$ LiDAR Digital Elevation Model.

available on the spot. But first it was very important to locate its position as accurately as possible. This was not easy for several reasons: a) the cave entrance is relatively small, b) the cave entrance coordinates in the cave registry were incorrect, c) only one photo of the vicinity of the cave entrance from 1974 exists (Fig. 2a), and d) the existing protection dyke is very big. A very rough estimate was that there were at least $5 \mathrm{~m}$ of debris above the cave entrance. The main question was: Is there a geophysical method that could locate the cave entrance accurately? Due to the given conditions - limestone debris overlying limestone rocks, and a very rough surface - it was decided that only Ground Penetrating Radar (GPR) could contribute to the solution, but success was not guaranteed mainly because the cave entrance is relatively small. Since it was known that the entrance was located in a depression within the rugged karstified surface, it was more likely that the original surface topography would be revealed than to detect the cave entrance itself, due to the signal resolution limit. But we hoped that the cave entrance could also be located in such an indirect way. We decided to apply special $50 \mathrm{MHz}$ rough terrain antennas which enabled measurements across the rugged surface (Mala, 2010). Seven GPR profiles were measured, aiming to reveal the original topography of the karstified surface under the debris with depth penetration of at least 10 meters.
Detection of underground voids for various purposes is a typical application of the GPR method. It can be used to assess geotechnical hazards related to the sudden collapse of natural or artificial cavities like abandoned mines or other underground excavations (Benson 1995). Most frequently, the detection of shallow cavities (at a depth less than $5 \mathrm{~m}$ ) is described in literature, because shallow features pose the main hazard for any surface construction or are interesting from the archaeological point of view (Pueyo-Anchuela et al., 2009b). High frequency GPR systems in the range from $200 \mathrm{MHz}$ to $500 \mathrm{MHz}$ are therefore usually applied because they have an appropriate depth penetration, but retain a good spatial resolution needed to detect small cavities as well. But for specific projects such as the construction of a tunnel through karstified rock, it is also important to detect larger cavities at greater depths. For a medium depth range of up to $20 \mathrm{~m}$, this can be accomplished by the application of low frequency (25-100 MHz) GPR systems.

\section{THE S-19 CAVE}

At the time of early speleological investigations in the Mt. Kanin massif, the S-19 Cave was the deepest explored and thus one of the most promising caves discovered (Pirnat, 2002). Although a very large number of shafts were investigated and documented, 
most of the caves were very shallow and terminated with debris or snow taps after the entrance shaft. The cave which was explored below the critical first tens meters' depth was thus very important. The S-19 Cave is located at the elevation of $1655 \mathrm{~m}$ in the Skripi area, which is located between two prominent side ridges formed by glacial erosion (Fig. 1) and is entirely developed in Upper Triassic Dachstein limestone. According to the cave registry of the Speleological Association of Slovenia (Čekada et al., 2011), the entrance shaft is $8 \mathrm{~m}$ deep and relatively narrow, $1 \mathrm{~m}$ by $0.5 \mathrm{~m}$. However, this information is not necessarily correct, since the entrance seems wider on the cave map presented in Fig $2 \mathrm{~b}$, at least in one direction. Unfortunately, no direct photo of the cave entrance is available, since the only one from 1974 (presented in Fig. 2a) does not clearly show the entrance itself. From this photo and from personal communication of speleologists, the entrance is located in a small depression within the rugged karstified surface. A good cave map was prepared (Fig. 2b) from which it is evident that the cave continues at the bottom with another open shaft (question mark on Fig. 2b). The cave is characterized by a series of shafts, which are

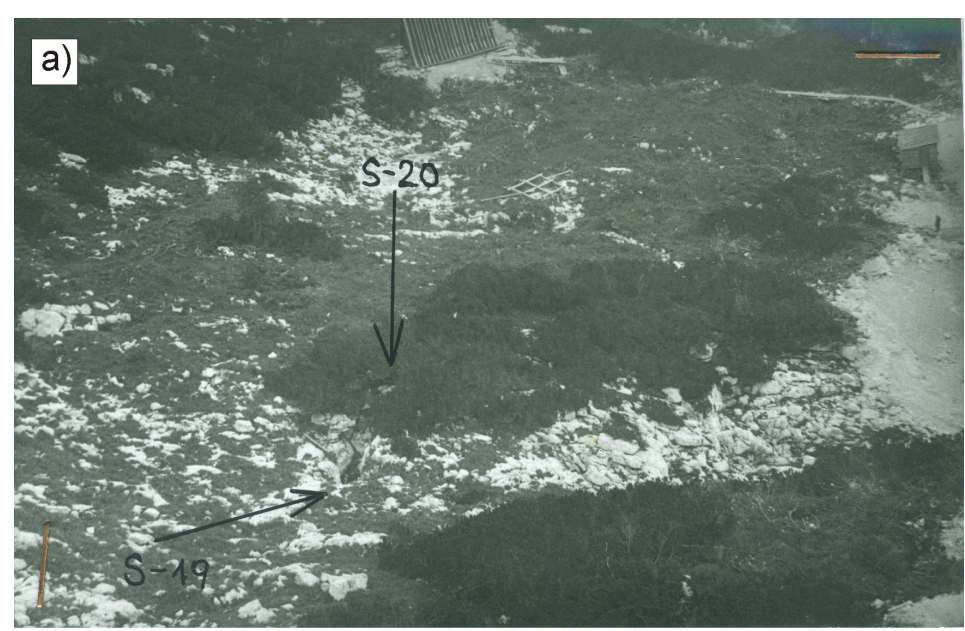

b)

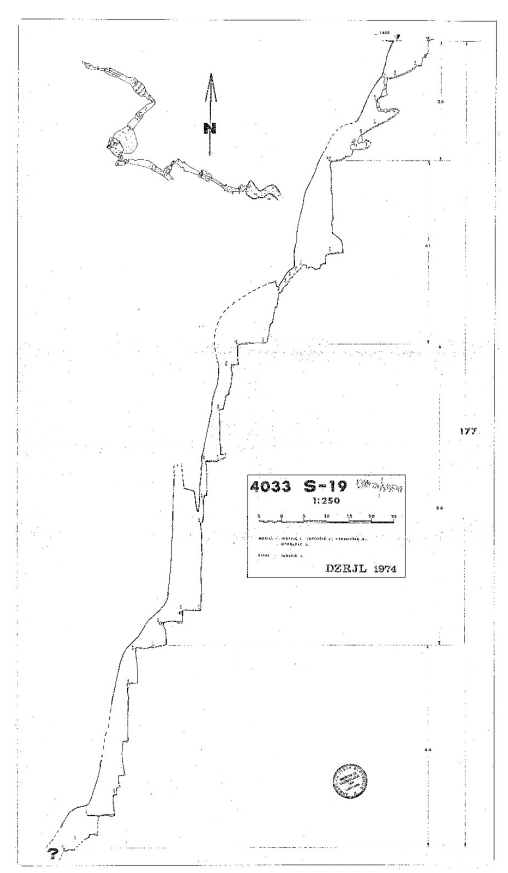

Fig. 2. a) Photo of the Skripi area from 1974 with marked entrances of the S-19 and S-20 caves (Foto: J. Jurečič); b) Extended profile and ground plan of the S-19 cave (courtesy of the Speleological Association of Slovenia cave registry). connected by short and narrow meanders. Another small shaft S-20 (Fig. 2a) in the vicinity of the S-19 Cave was explored to the depth of $12 \mathrm{~m}$, but it ends with a debris tap. Although the Cave S-19 is well documented in the cave registry, the coordinates of its entrance are incorrect; it is marked at approx. $200 \mathrm{~m}$ to the NE from its actual location (Čekada et al., 2011). Such a mistake is surprising, because a nearby shelter and the cable-car station already existed in 1974 (Fig. 2a). Therefore, one would expect that the cave entrance position would be better determined on the topographic map in a 1:10,000 scale, which is specified as a source of its coordinates.

In 1973 a cable-car was constructed from the town of Bovec to the plateau at the elevation of $2202 \mathrm{~m}$ (station D) and a new skiing area opened in 1974 (Kunaver et al., 2011). The intermediate C-station Skripi (Figs. 3 and 4) was constructed on a small plateau, only $70 \mathrm{~m}$ from the S-19 Cave entrance, in an area exposed to snow avalanches. Since the rugged karstified surface is not suitable for skiing, large rock and soil works were conducted to prepare the skislopes in the intermediate vicinity of the cave (Fig. 1), but at that time the cave entrance remained open. In the winter 1974/75 a big avalanche happened in the Skripi area and partially destroyed the cablecar C-station. The danger of snow avalanches in this area was definitely underestimated, although artificial triggering of avalanches was regularly conducted during the winter. Therefore, to deviate avalanches away from the station a huge dyke of limestone debris was constructed around the station at the distances between 50 and $200 \mathrm{~m}$ (Kunaver et al., 2011). Also the entrance of the S-19 Cave was buried under thick layer of debris. Therefore, it seemed that the cave entrance would remain buried forever.

After another cable-car accident, renovation activities started in 2015, including large rock and soil works in the vicinity of the C-station. Speleologists decided that this was a unique opportunity to excavate the S-19 Cave entrance. With the support of the local community and through negotiations with the contractor, an agreement was achieved to at least try to do this. But prior to any dredger excavation attempt, the key question was how exactly could the cave entrance be located based on all available information from 1974 and through the application of possible search techniques, among which the GPR was selected as the most promising method.

\section{THE GROUND PENETRATING RADAR METHOD}

After earlier applications of the ground penetrating radar (GPR) method in specific conditions of permafrost and ice covered areas, the method started to develop rapidly for investigations of the shallow subsurface around 25 years ago (Davis \& Annan, 1989). The method has been successfully applied to solve various geological, geotechnical, engineering, environmental and archaeological problems in the 
depth range from a couple of centimetres to several tens of meters or even hundreds of meters in case of penetrating ice. Furthermore, applications of the GPR method have emerged in some new fields over the last decade, for instance in forensic, agricultural, and soil sciences (Reynolds, 2011). However, among geological problems the most common applications are related to investigations of the bedrock depth, stratigraphy and sedimentology of sediments, faults, and fracture zones, delineation of rock fabric, determination of water table depth, identification of karst features, and detection of voids (Daniels, 2004; Jol, 2009; Reynolds, 2011).

The principle of the GPR method is that a short pulse of high frequency (25-2,000 $\mathrm{MHz}$ ) electromagnetic (EM) energy is transmitted into the ground where it is reflected from the interfaces which separate layers with different electrical properties. The reflected

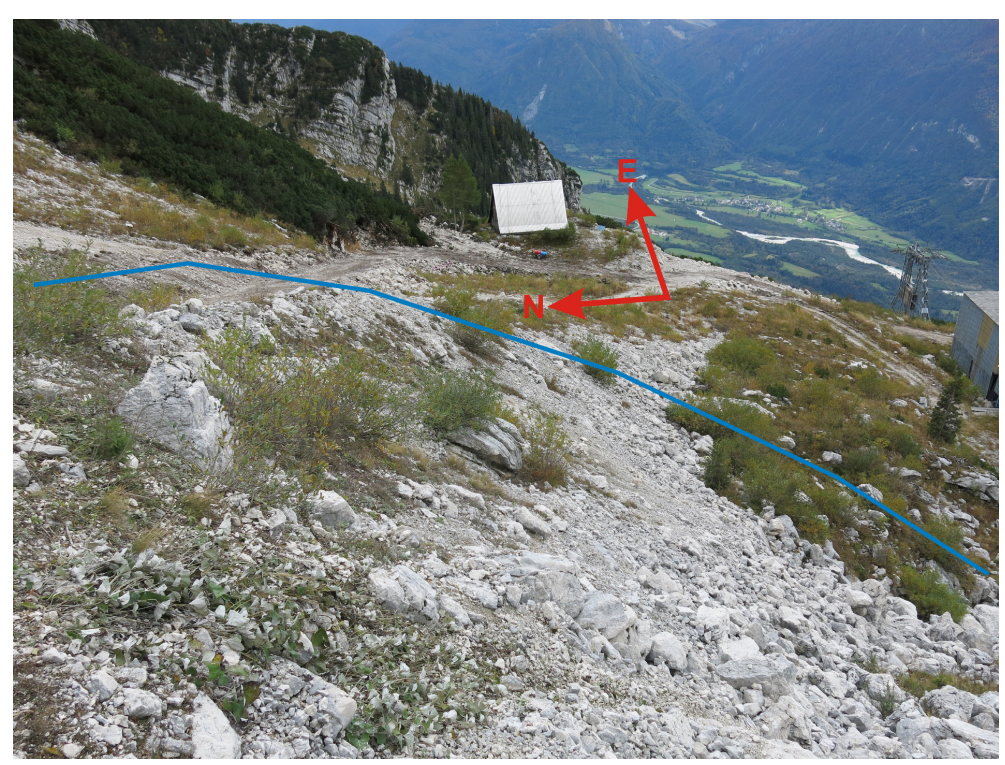

Fig. 3. Photo of the Skripi area from 2015 at the time of the GPR measurements. The entrance of the S-19 cave is covered by a thick layer of debris. At the top of the picture the same shelter as in Fig. 2a is visible and at the right the cable-car C-station. Blue line shows the NE limit of the study area.

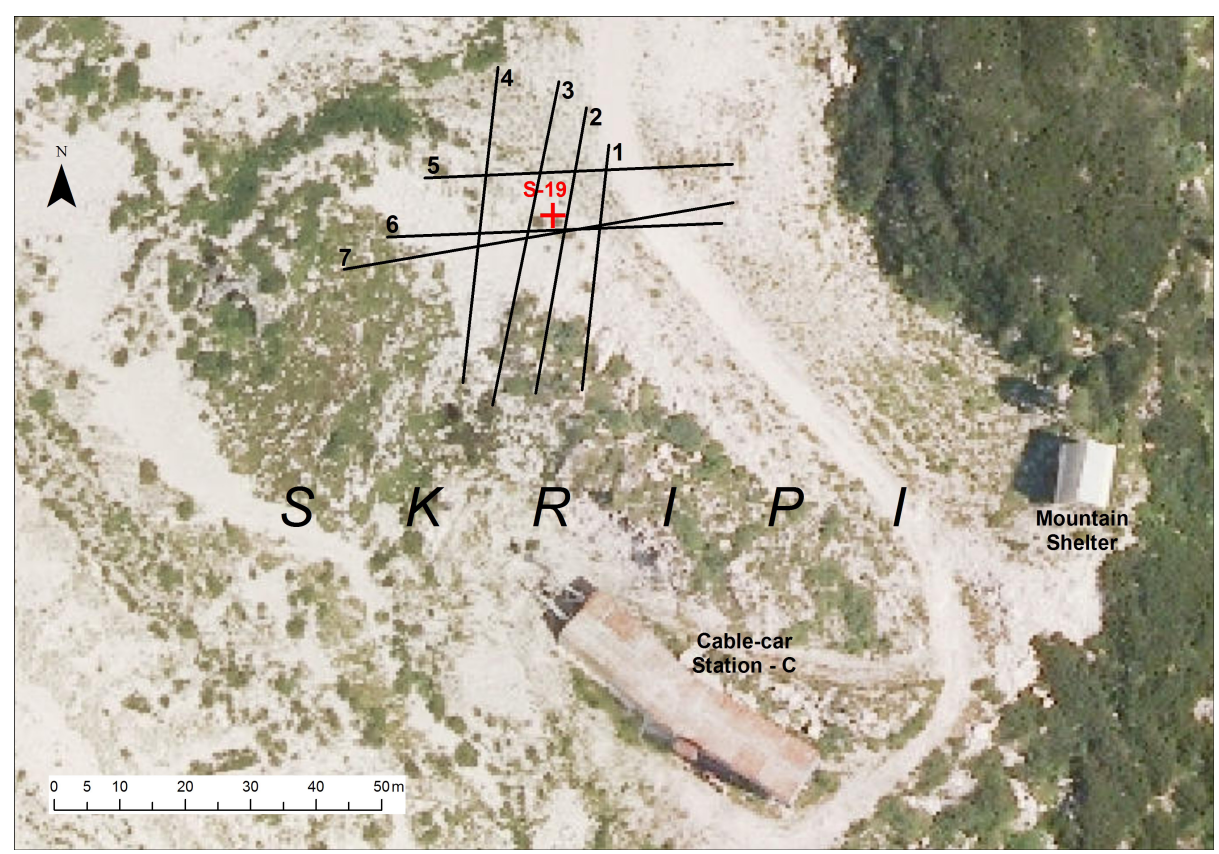

Fig. 4. Position map of the GPR profiles. Aerial image of Surveying and Mapping Authority of Slovenia (GURS) signal is detected by the receiver antenna, amplified, digitized, and stored for later data processing. The GPR is normally used in a common-offset reflection mode using a pair of properly spaced antennas which are moved along the straight measuring profile.

The propagation of EM waves through the rocks is controlled by dielectric and conductivity properties of the material. The velocity of wave propagation $V$ in low-loss geologic materials depends on the relative dielectric permittivity (dielectric constant) $\varepsilon$ by the equation:

$$
\mathrm{V}=\mathrm{c} / \varepsilon^{0.5}
$$

where $c=3 \cdot 10^{8} \mathrm{~m} / \mathrm{s}$ or $30 \mathrm{~cm} / \mathrm{ns}$, the propagation velocity of EM waves in vacuum.

The attenuation of EM waves depends mainly on the conductivity of the material. Since the presence of water in rocks is the main factor which controls the conductivity, the GPR method is most suitable for dry rocks where the greatest depth of penetration can be achieved. The second factor which controls the depth of penetration and data resolution is the frequency of the EM signal: the lower is frequency, the deeper is penetration and the resolution is lower. Antennas which transmit and receive signals with different central frequencies should therefore be used for different purposes.

Among geophysical methods the GPR has been increasingly used in the last decade in karst areas for solving different issues related to environmental, hydrogeological, and geotechnical investigations. According to Chalikakis et al. (2011), the GPR method is the most popular geophysical tool for identification and characterization of subsurface karst features such as cavities, channels, conduits, and solutionally enlarged fractures. Martinez-Moreno et al. (2013) give an overview of geophysical studies which have been used to detect shallow caves, including the approximate penetration depth, which is between 4 and $28 \mathrm{~m}$ for the GPR method.

Natural cavities and sinkholes which pose potential hazards can be related to the dissolution of various materials like salt and anhydrite (e.g., Frumkin et al., 2011; Mochales et al., 2008), but most frequently they are characteristic of karstified limestone (e.g., Sharma, 1997; McMechan et al., 1998; Chamberlain et al., 2000; PueyoAnchuela et al., 2009a; Gosar, 2012). Many studies of cavities, frequently combining several geophysical methods, have mainly been focused on determining their location, spatial distribution, and extension (e.g., Beres et al., 2001; Vadillo et al., 2012; Seren 
et al., 2012). An important task for engineering is detecting and locating underground cavities beneath constructions and populated areas (e.g., El-Qady et al., 2005) and locating fractured zones in order to evaluate the stability of the karstic caves (Leucci \& De Giorgi, 2005). Detection of hazardous cavities, subsidence sinkholes, and sagging in karst terrain as potential geohazard assessment is necessary particularly in populated sites. Recently, several studies have successfully applied the GPR method with other geophysical surveys and techniques in order to evaluate and predict the risk of sinkhole collapses in urban areas (Murphy et al., 2008; Delle Rose \& Leucci, 2010; Gomez-Ortiz \& MartínCrespo, 2012; Carbonel et al., 2014; De Giorgi \& Leucci, 2014; Pueyo-Anchuela et al., 2015). Karst cavities are also investigated by the GPR to prevent geohazards in mineral exploitation (Zajc et al., 2014; Zajc et al., 2015). The GPR is also widely used in archaeology to detect underground chambers which can have significant archaeological meaning, such as vaults, culverts, and crypts (e.g., Basile et al., 2000; Leucci \& Negri, 2006; Piscitelli et al., 2007).

\section{DATA ACQUISITION AND PROCESSING}

The GPR profiles were measured using the Mala ProEx recording unit and $50 \mathrm{MHz}$ antennas (Mala, 2010) with a common offset technique. Special rough terrain antennas (RTA) recently developed by Mala were used due to the very rough surface, because it was clear that the application of rigid antennas was impossible. Compared to normal unshielded antennas, which are usually oriented perpendicularly to the profile direction and are rigid, the RTA antennas are flexible, in-line oriented, allin-one antennas (Mala, 2010). The flexible snake-like design in the form of a long tube allows the antenna to be manoeuvred easily and efficiently over the uneven terrain without affecting ground contact, providing optimum results even in difficult conditions. The most important benefit is that it is not necessary to clear the profile route prior to the survey to make it flat or vegetation free. The total length of a $50 \mathrm{MHz}$ RTA is $9.25 \mathrm{~m}$ and the spacing between antennas is $4 \mathrm{~m}$.

Seven GPR profiles (Fig. 4 and Table 1) were measured in difficult terrain conditions characterized by a very rough and sometimes also very steep surface that caused severe difficulties for traversing the area with sensitive equipment. The profile lengths were between 37 and $60 \mathrm{~m}$. Most of the profile distances were measured across the debris infill which also includes large rock blocks (Fig. 5); only the initial parts of $\mathrm{S}-$ $\mathrm{N}$ oriented profiles were measured across karstified limestone bedrock. Although
RTA antennas were used, a team composed of three people was necessary to successfully conduct the measurements: the operator who carried the acquisition unit in a backpack and a laptop computer in front of him and two assistants who took care of the proper movement of the antennas' tube and prevented it from being blocked by rocks or from losing their good contact with the ground (Fig. 5). Good ground contact along the whole length of the antennas was not always possible due to the rough surface and this was definitely an important source of noise in the radargrams. Although the basic idea was to measure a regular grid of profiles across the area where the cave entrance was supposed to be, the actual geometry of the measured profiles was fully influenced by terrain characteristics. Through initial tests we realized that only two directions of measurements were possible, in roughly $\mathrm{N}-\mathrm{S}$ and $\mathrm{W}-\mathrm{E}$ oriented profiles (Fig. 4 and Table 1). Four nearly parallel profiles were measured in the $\mathrm{S}-\mathrm{N}$ direction in $25 \mathrm{~m}$ wide band and three in the $\mathrm{W}-\mathrm{E}$ direction in $15 \mathrm{~m}$ wide band.
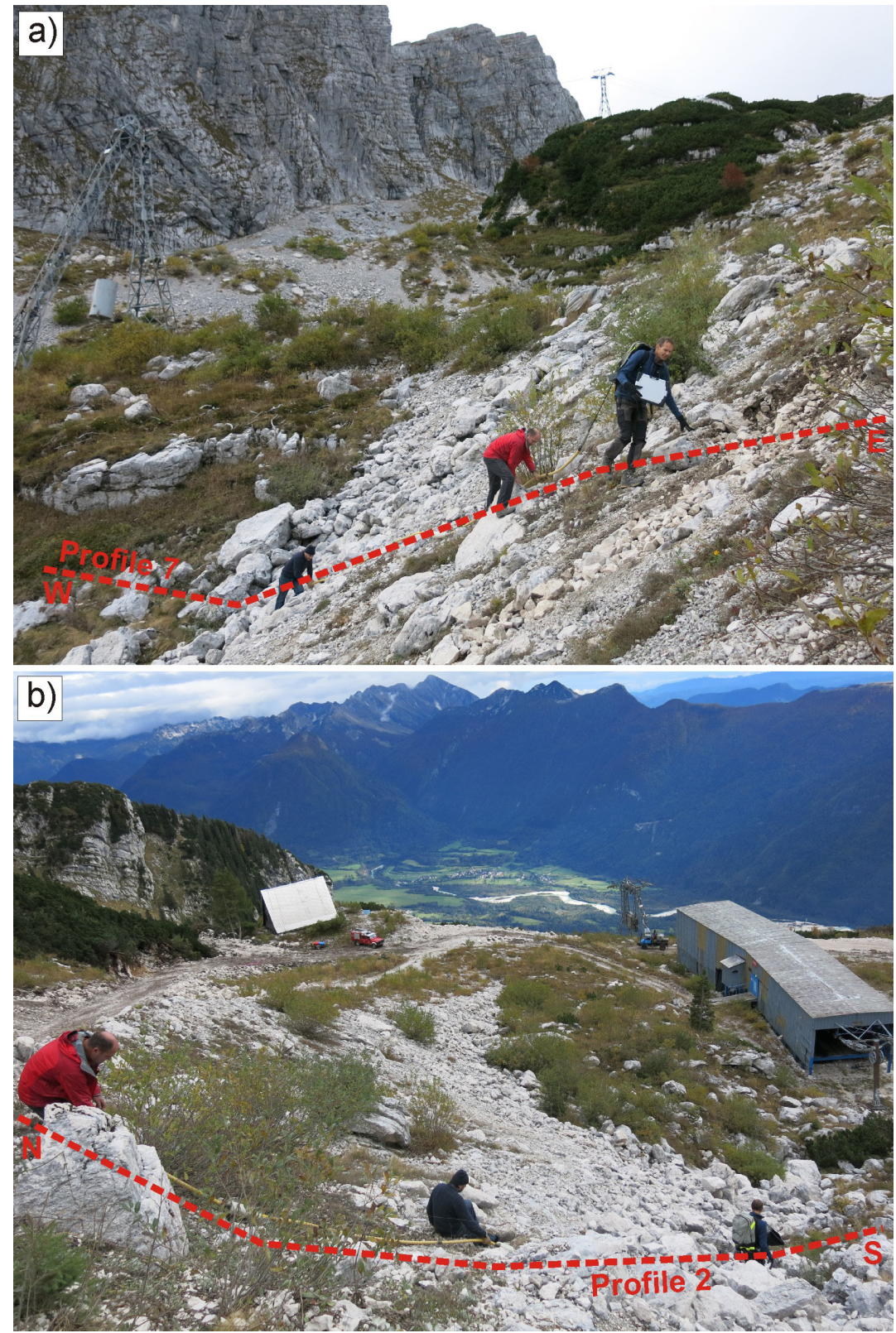

Fig. 5. Two photos of the GPR measurements performed in very difficult conditions characterized by steep slopes and a rugged surface: a) measurement of profile 7 , the view in NW direction; b) measurement of profile 2, the view in $\mathrm{E}$ direction. 
Table 1. Basic data on the measured GPR profiles.

\begin{tabular}{|c|c|c|c|}
\hline $\begin{array}{c}\text { Profile } \\
\text { number }\end{array}$ & Orientation & Length & $\begin{array}{c}\text { No. of GPR } \\
\text { traces }\end{array}$ \\
\hline 1 & $\mathrm{~S}-\mathrm{N}$ & $37.4 \mathrm{~m}$ & 187 \\
\hline 2 & $\mathrm{~S}-\mathrm{N}$ & $44.2 \mathrm{~m}$ & 221 \\
\hline 3 & $\mathrm{~S}-\mathrm{N}$ & $47.9 \mathrm{~m}$ & 240 \\
\hline 4 & $\mathrm{~S}-\mathrm{N}$ & $50.2 \mathrm{~m}$ & 251 \\
\hline 5 & $\mathrm{~W}-\mathrm{E}$ & $45.6 \mathrm{~m}$ & 228 \\
\hline 6 & $\mathrm{~W}-\mathrm{E}$ & $50.8 \mathrm{~m}$ & 254 \\
\hline 7 & $\mathrm{~W}-\mathrm{E}$ & $59.4 \mathrm{~m}$ & 297 \\
\hline
\end{tabular}

From the shape of the debris infill and the known original topography from the historical photo, it was a reasonable assumption that the cave would be within the investigated area. We initially wanted to measure an additional $\mathrm{W}-\mathrm{E}$ profile south of profiles 6 and 7 (Fig. 4), but this proved impossible due to big rock blocks. Unfortunately, we were not able to perform additional topographic (detailed elevation) survey of the profiles due to equipment/time limitations to enable application of GPR topographic correction. On the other hand, due to very specific objective of the study to locate the local depression with cave entrance, this was not absolutely necessary.

All seven profiles were measured twice, in a "direct" and "reverse" direction. This is helpful in difficult terrain conditions, because the noise caused by locally poor ground contact of the antennas can be quite different in two measuring directions. In case of non-horizontal reflections, the changes in radargrams recorded in different directions are related also to respect changes in the underground (Jol, 2009). In the case of four S $\mathrm{N}$ profiles (profiles 1-4) we realized that better results were obtained when the movement was up-slope, because it was easier to maintain a straight position of the antennas' tube than in the opposite, down-slope direction. Although there was some heavy rainfall in the area one day before the measurements took place, which could have influenced the penetration of the GPR signals due to wet sediments, the ground was dry enough because the water quickly drained through the debris and through the underlying karstified rocks. A good signal penetration of $15-20 \mathrm{~m}$ was therefore achieved, which is expected for a low frequency (50 MHz) GPR system in favourable lithological setting without the presence of clay sediments.

To conduct measurements in regular intervals (0.2 $\mathrm{m}$ was selected) two different triggering systems are used in common GPR systems. The first is a distance-measuring wheel which is used with highfrequency all-in-one antennas that are towed or pushed along the profile. In our case it was clear that the distance-measuring wheel could not operate at all on such a rough surface. The second is a chain (leash) profile encoder composed of a leash and a wheel which is rotated by unwrapping the leash and triggers the acquisition in regular distance intervals. Such a chain profile encoder was used in our measurements as the single possibility to maintain regular triggering intervals. The signal sampling frequency was $1000 \mathrm{MHz}$ and the acquisition time window was 1024 ns long. All of the GPR acquisition parameters are summarized in Table 2.
Table 2. GPR acquisition parameters.

\begin{tabular}{|l|l|}
\hline Antennas & $\begin{array}{l}50 \mathrm{MHz} \text { unshielded rough terrain } \\
\text { antennas (RTA) }\end{array}$ \\
\hline Antennas' separation & $4 \mathrm{~m}$ \\
\hline Sampling frequency & $1000 \mathrm{MHz}$ \\
\hline Sampling interval & $1 \mathrm{~ns}$ \\
\hline Acquisition length & 1024 samples $=1024 \mathrm{~ns}$ \\
\hline Stacks & 16 \\
\hline Trace spacing & $0.2 \mathrm{~m}$ \\
\hline Triggering system & chain (leash) encoder \\
\hline
\end{tabular}

Data was processed using the following processing sequence:

- DC removal

- Time zero adjustment

- Background removal

- Amplitude correction (AGC)

- Bandpass filtering

- Time to depth conversion

No topographic correction was applied to the data, since we were not able to perform detailed geodetic survey along the profiles. The real debris-bedrock contact topography was therefore not derived from the profiles, but the goal to locate the local depression with the cave entrance was achieved also without such correction. Time to depth conversion was performed using the constant velocity of $11.3 \mathrm{~cm} / \mathrm{ns}$ typical for limestone, which corresponds to the dielectric constant $\varepsilon=7$ (Table 3 ), since no lithological changes were expected along the investigated depth of penetration. This figure corresponds well to the central value for dry limestone in literature where the $\varepsilon$ spans from 4 to 9 (Daniels, 2004; Jol, 2009; Reynolds, 2011). We also tried some hyperbola fitting for signal velocity determination for few diffractions visible on radargrams and obtained similar values of around 11 $\mathrm{cm} / \mathrm{ns}$. The $50 \mathrm{MHz}$ GPR signal wavelength in such a material is $2.3 \mathrm{~m}$ and the theoretical vertical and horizontal resolutions at the depth of $10 \mathrm{~m}$ are $1.1 \mathrm{~m}$ and $4.1 \mathrm{~m}$, respectively (Table 3).

Table 3. Data on the GPR signal velocity and wavelength.

\begin{tabular}{|l|l|}
\hline Antennas' central frequency & $50 \mathrm{MHz}$ \\
\hline Wavelength $(\lambda)$ in air & $6 \mathrm{~m}$ \\
\hline Average dielectric constant $(\varepsilon)$ of limestone & 7 \\
\hline EM velocity in limestone & $11.3 \mathrm{~cm} / \mathrm{ns}$ \\
\hline Wavelength $(\lambda)$ in limestone & $2.3 \mathrm{~m}$ \\
\hline Vertical resolution at $10 \mathrm{~m}$ depth & $1.1 \mathrm{~m}$ \\
\hline Horizontal resolution at $10 \mathrm{~m}$ depth & $4.1 \mathrm{~m}$ \\
\hline
\end{tabular}

\section{RESULTS AND INTERPRETATION}

The processed GPR profiles are shown in Figs. 6-8 and their position map in Fig. 4. All the profiles are shown as two-way-traveltime (vertical axis in nanoseconds) sections (radargrams) with an additional depth scale in meters. On the horizontal axis the profile distance in meters is shown, as well as trace numbers (trace spacing is $0.2 \mathrm{~m}$ ). In general, the signal to noise ratio on the recorded radargrams is good. The main source of noise is most probably related to locally poor ground contact of the antennas due to the rough surface. Such noise is visible in 
radargrams as distinct vertical stripes, for example: traces $10-45$ on Profile 1 , traces $125-140$ on Profile 2, traces $190-210$ on Profile 3 , traces $120-125$ on Profile 4, traces 65-75 on Profile 5, traces 50-65 on Profile 6, and traces 200-220 on Profile 7. Another source of noise is related to large blocks inside the debris infill, which are not big enough to be clearly imaged at given horizontal resolution, but produce a strong signal scattering. Since there were no above the ground objects in the surveyed area, such as trees, pillars, or power lines, there were no problems with the so-called air-reflections which can be a very problematic source of noise in some regions when using unshielded GPR antennas, especially in forests or in urban areas.

The preliminary interpretation of radargrams has shown that the cave entrance itself, as an open space (void) inside the limestone, is not visible on any radargram. This was not surprising since the cave entrance is very narrow and most probably filled with debris. If there is a large enough cave chamber or gallery, it is normally visible on the radargram as a distinct hyperbolic shape of reflections (Gosar, 2012). On some radargrams, there are in fact some hyperbolic diffractions visible below the debris infill, but they cannot be an indication of a cavity. They resulted from multiple reflections inside a concaveshaped local depression. Such hyperbolic features are visible in Profile 1 (traces 120-150), Profile 2 (traces 155-185), and Profile 5 (traces 75-115).

Since it was clear that the cave entrance could not be directly detected, the interpretation was targeted to reveal the shape of the contact between the artificial infill composed of debris and the limestone bedrock as accurately as possible. In all profiles there is a clearly visible difference in the character of reflections between the upper part (the green-coloured layer in Figs. 6-8) and the lower part. It was interpreted as a boundary between the debris infill and the bedrock. The debris infill is characterized by a near absence of reflections or by very weak reflections. Only in certain parts (traces 160-210 in Profile 3, traces 180-225 in Profile 6, and traces 5-80 in Profile 7) there are strong subhorizontal reflections visible within this layer, but their origin is unknown. On the other hand, the underlying bedrock is mostly characterized by a series of strong reflections just below the boundary, visible down to the maximum depth of around $13 \mathrm{~m}$. In greater depths the radargrams are characterized by an absence of any reflections due to the homogeneous limestone.

The contact between the artificial debris infill (green-color in Figs. 6-8) and limestone bedrock was carefully traced and interpreted on all radargrams. In four $\mathrm{N}-\mathrm{S}$ oriented profiles (Figs. 6 and 7), a very clear depression in the contact is visible with the deepest point at $7 \mathrm{~m}$ in Profile 1, $6 \mathrm{~m}$ in Profile 2, $6 \mathrm{~m}$ in Profile 3 , and $6.5 \mathrm{~m}$ in Profile 4 . The depression is nearly symmetrical and does not change its shape much in the $25 \mathrm{~m}$-wide band covered by these four profiles. The initial southern parts of all profiles were measured on the bedrock, therefore no debris infill is visible there. On the other hand, all profiles terminate in the north within the debris infill, which is still around
$4 \mathrm{~m}$ thick there. All three W-E oriented profiles (Fig. 8) were measured in their total lengths across the debris infill, but its thickness varies considerably, revealing a clear shape of a reverse arch-shaped depression in the bedrock topography. At the deepest point all the profiles show the maximum debris thickness of around 6.5-7.5 m. Elsewhere on the profiles, the debris thickness varies between 4.5 and $6.5 \mathrm{~m}$.

Based on the interpretation of the contact between the debris infill and the bedrock in all seven GPR profiles, the local minimum in the topography was determined at the point indicated with a cross in Fig. 4 as the most probable location of the S-19 Cave entrance. The maximum thickness of the debris at this point was determined to be $6.5-7 \mathrm{~m}$. This location was marked in the field by a red pole (Fig. 9).

A thickness of 6-7 $\mathrm{m}$ and a very loose debris infill, which also includes some large rock blocks, presented a big challenge for the excavation of the cave by the dredger (Fig. 10a), followed by manual work of speleologists. The substantial effort was rewarded by the actual opening of the cave entrance at the location determined by the GPR measurements. The estimated depth of $7 \mathrm{~m}$ was proved to be precise. A big supporting wall made of rock boulders (Fig. 10b) was built to protect the nearby road from collapsing. A metal tube was then installed into the cave entrance to enable permanent access to the cave and the debris infill put back in place.

\section{CONCLUSIONS}

Geophysical investigations have an important role in karst exploration. They are aimed at solving a wide range of different problems, from the mitigation of geotechnical hazards for infrastructural projects to the search and protection of groundwater resources. The detection of underground caves, galleries, and chambers for speleological or groundwater investigations or to avoid unexpected and dangerous surface collapses is among the interesting cases of a successful application of different geophysical methods. A very specific case of a search for a cave entrance which was buried by an artificially built protection dyke was presented in our study. A low frequency GPR method was selected as the only applicable method in given conditions. Although the investigated area is characterized by a very rough surface, measurements using special rough terrain antennas were successfully conducted. Since the cave entrance is quite narrow, it was impossible to directly detect the cavity itself. Knowing the approximate original topography of the area before a thick layer of debris was put in place, we hoped that it would perhaps be possible to find the cave entrance by locating the exact position of the local depression inside the rugged karstified terrain. The acquired radargrams have shown a clear difference in signal characteristics between the debris infill and the limestone bedrock. By a careful interpretation of the debris-bedrock contact we revealed the shape of a local depression and determined its deepest point as the most probable location of the cave entrance at the depth of approx. $7 \mathrm{~m}$. Topographic correction which 


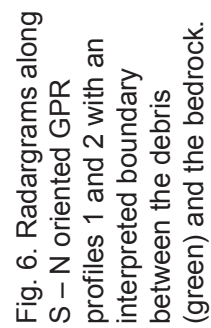

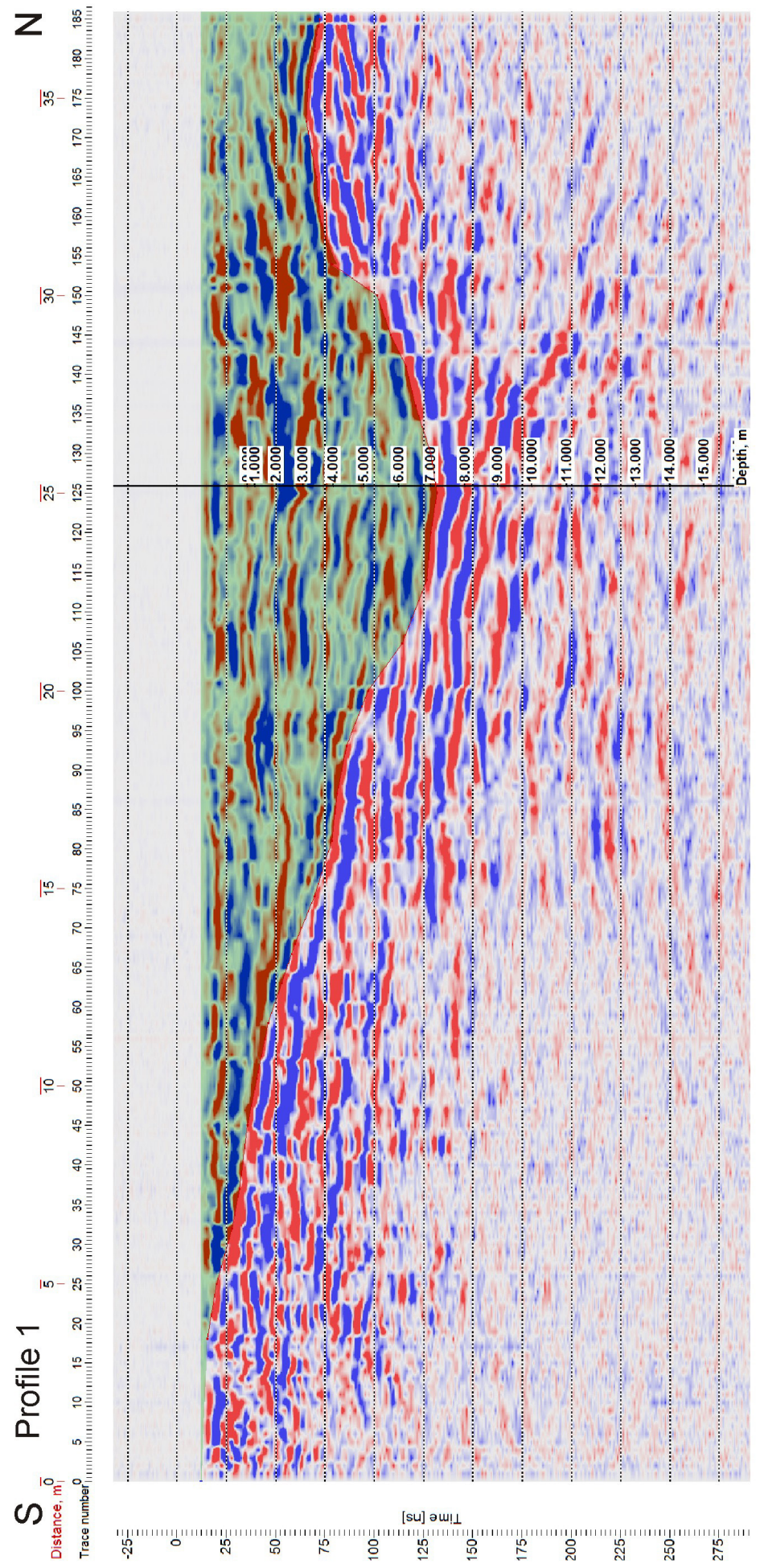

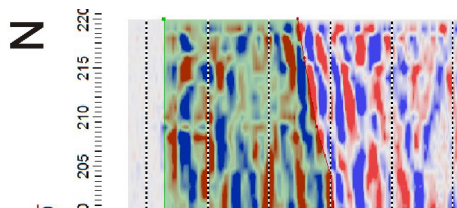

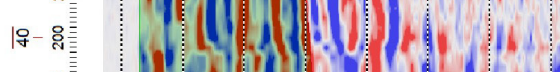

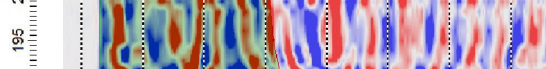

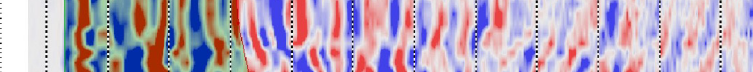

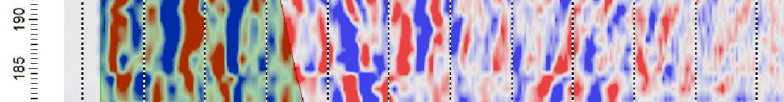

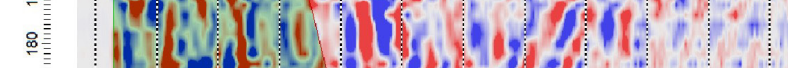

舟-

을

(3)

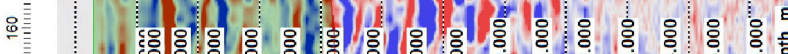

(1)

品- 吕高

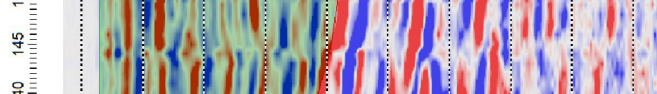

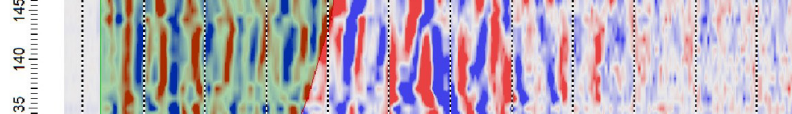

镕

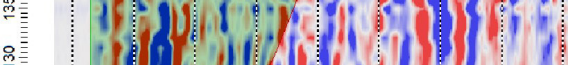

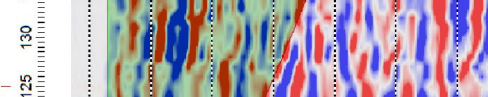

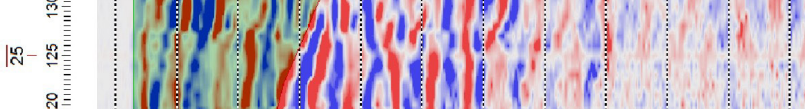

o

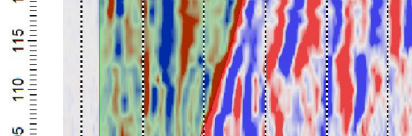

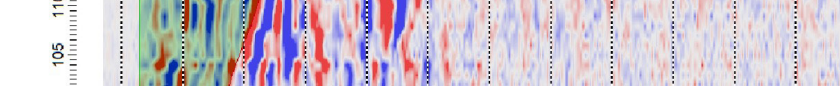

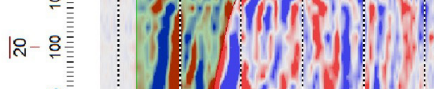

$$
\text { s) }
$$

$$
\text { 品 }
$$

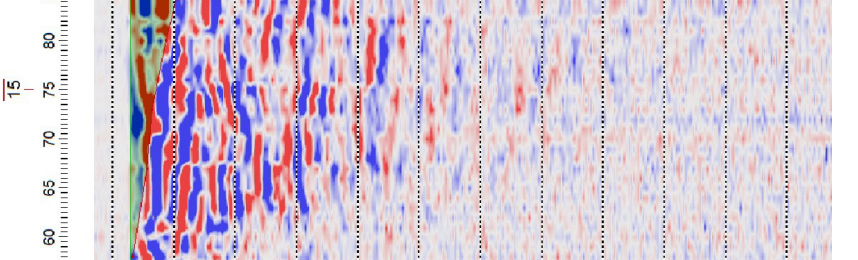

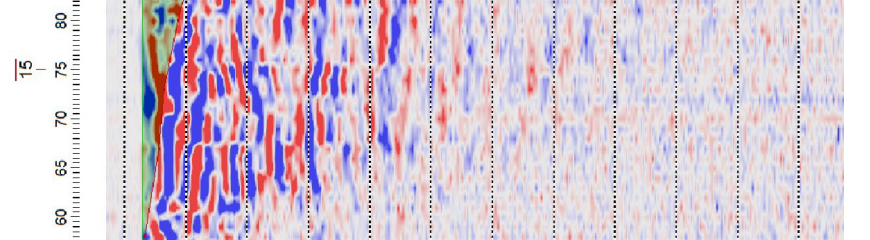

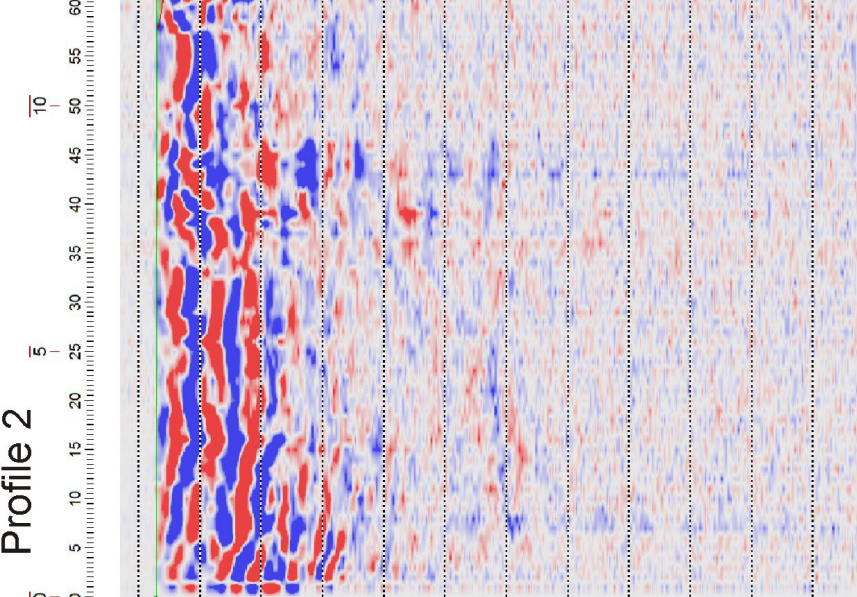

$\boldsymbol{C}$ 


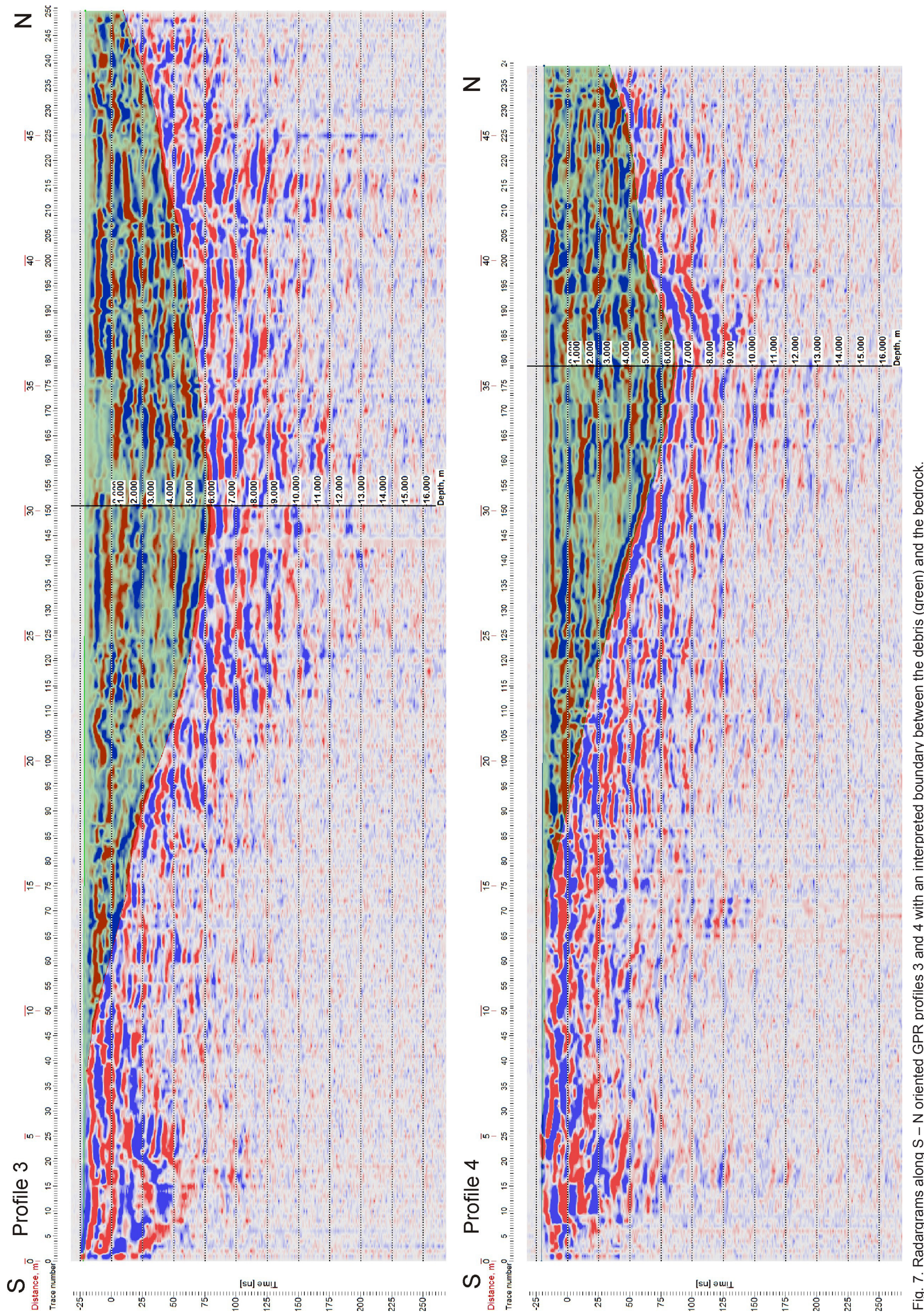



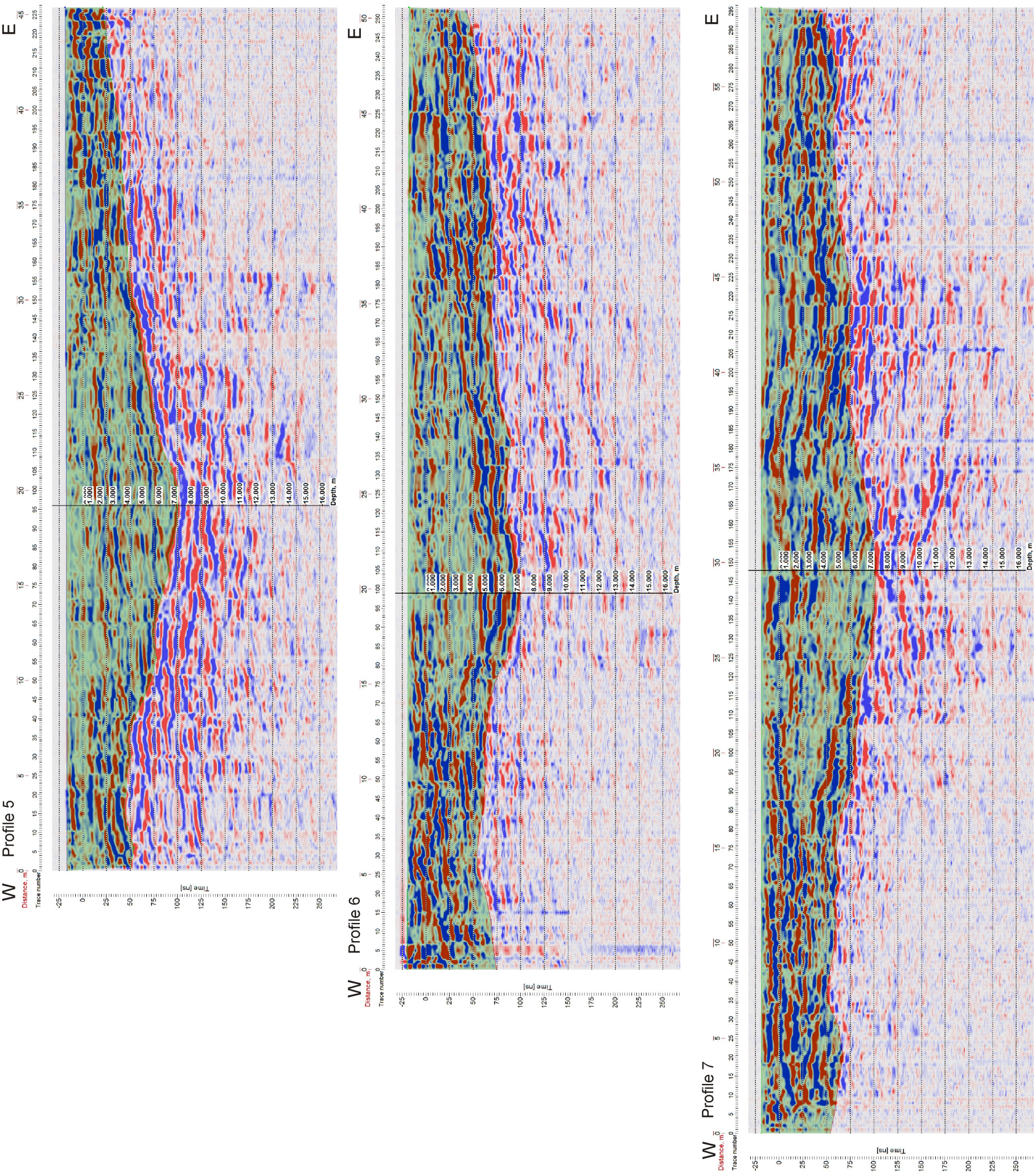


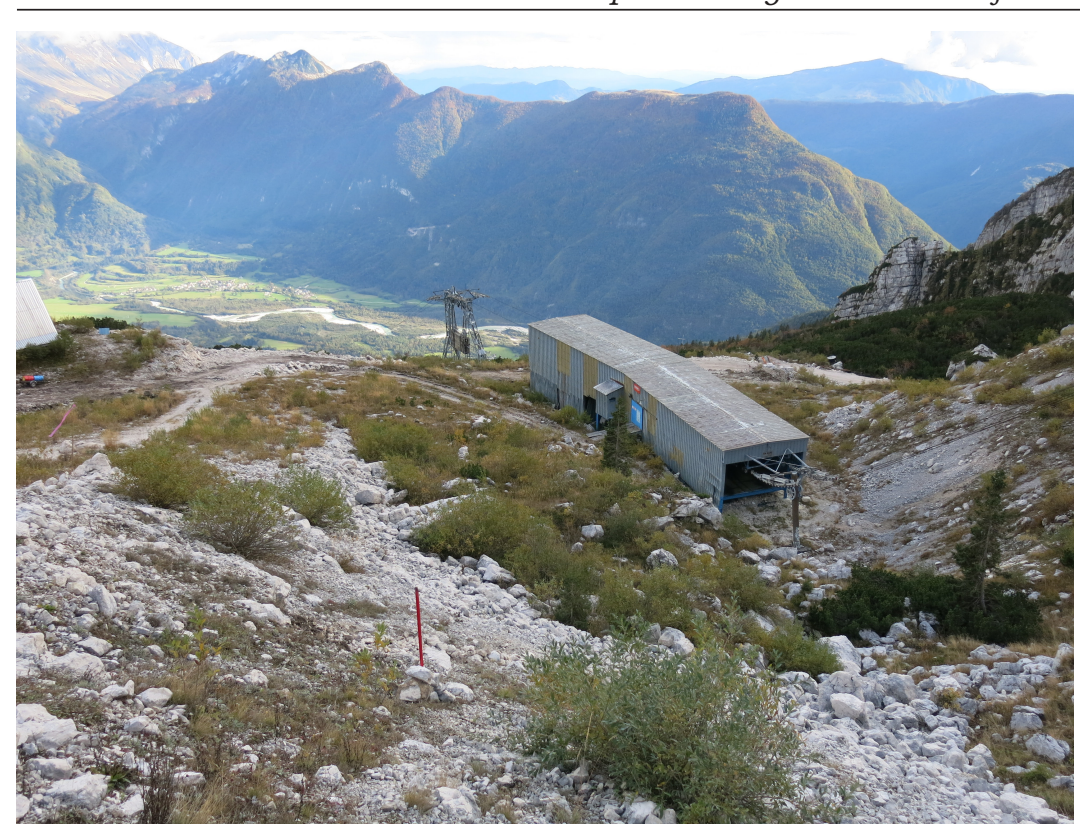

Fig. 9. The photo of the investigated area. The location of the cave entrance as determined from the GPR investigations is shown with a red pole.
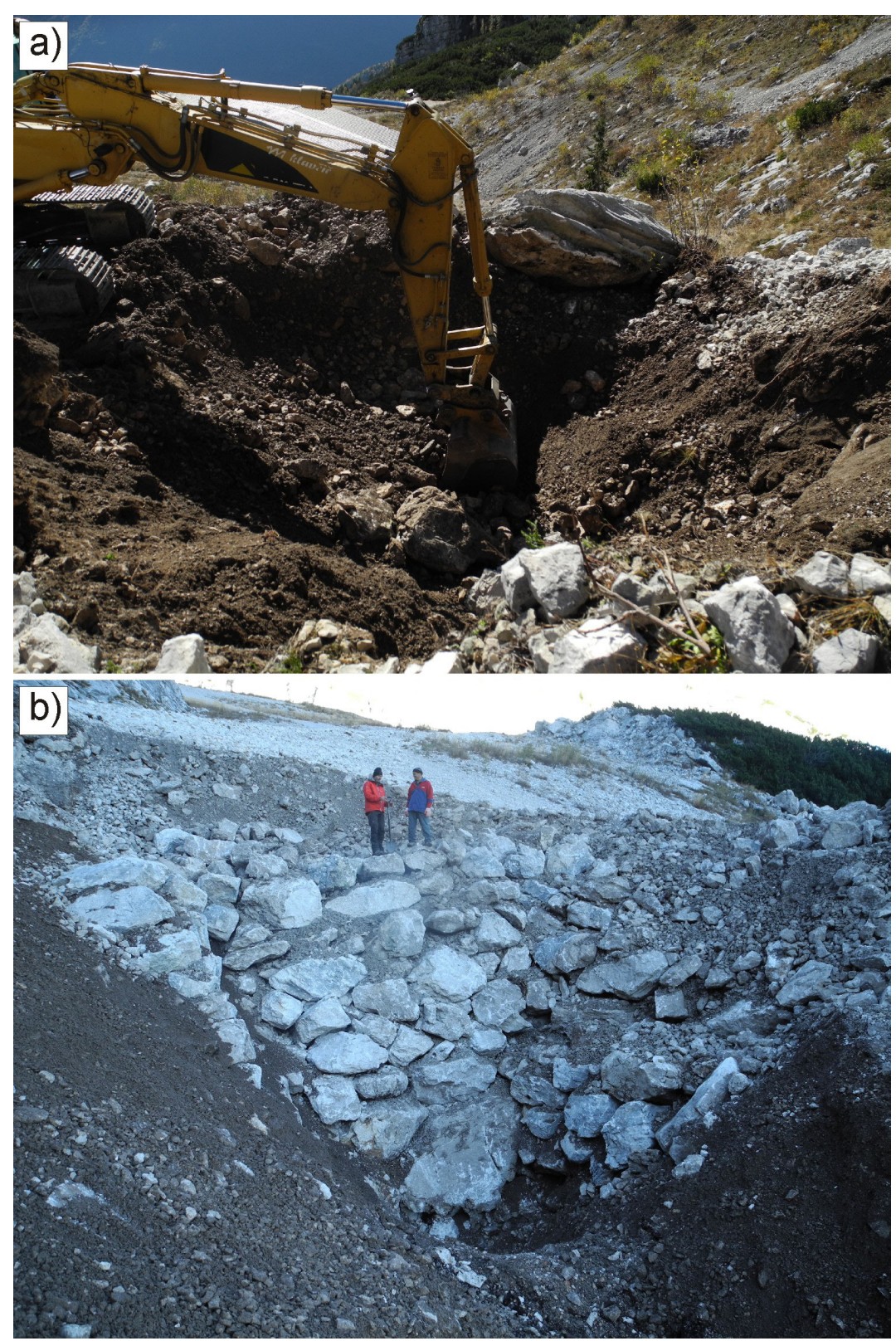

Fig. 10. a) Excavation of the cave entrance by the dredger; b) situation after completing the dredger excavation; loose debris material required building a protection wall built from rock boulders (Foto: G. Pintar). should normally be applied to GPR data was omitted due to equipment/time limitations, which is acceptable approach only for such rather specific case to find local minimum in debris-bedrock contact. A large excavation performed by a dredger followed, proving that the cave entrance was properly located and the thickness of debris precisely estimated. The application of the advanced geophysical method therefore proved successful in providing a solution to this very specific case in karst exploration and the S-19 Cave in the Mt. Kanin massif, which is very important from the speleological point of view and is also an example of natural heritage, was made accessible again.

\section{ACKNOWLEDGMENTS}

This study was conducted with the support of the research programme P1-0011 and the Ph.D. grant 1000-15-0510 financed by the Slovenian Research Agency. This work also benefited from networking activities carried out within the EU-funded COST Action TU1208 "Civil Engineering Applications of Ground Penetrating Radar". The authors are grateful to Gregor Pintar, Daniel Rojšek, and Andrej Drevenšek for their help in the organisation of field measurements and providing historical and recent data and photos on the S-19 Cave. The company Kaskader from Idrija did a massive work in dredger excavation of the cave entrance. This was supplemented by arduous and sometimes dangerous manual digging effort of the members of the Society for Cave Exploration from Ljubljana to finally open the shaft and to build in the protection (tube) for a permanent access into the cave. All of them are acknowledged for their contribution.

\section{REFERENCES}

Basile V., Carrozzo M.T., Negri S., Nuzzo L., Quarta T. \& Villani A.V., 2000 - A groundpenetrating radar survey for archaeological investigations in an urban area (Lecce, Italy). Journal of Applied Geophysics, 44 (1): 15-32. http://dx.doi.org/10.1016/S0926-9851(99) $\underline{00070-1}$

Benson A.K., 1995 - Applications of ground penetrating radar in assessing some geological hazards: examples of groundwater contamination, faults, cavities. Journal of Applied Geophysics, 33: 177-193

http://dx.doi.org/10.1016/0926-9851(95) 90040-3

Beres M., Luetscher M. \& Olivier, R., 2001 Integration of ground-penetrating radar and microgravimetric methods to map shallow caves. Journal of Applied Geophysics, 46: 249-262.

http://dx.doi.org/10.1016/S0926-9851(01) $\underline{00042-8}$ 
Carbonel D., Rodríguez V., Gutiérrez F., McCalpin J.P., Linares R., Roqué C, Zarroca M., Guerrero J. \& Sasowsky I., 2014 - Evaluation of trenching, ground penetrating radar (GPR) and electrical resistivity tomography (ERT) for sinkhole characterization. Earth Surface Processes and Landforms, 39 (2): 214-227. http://dx.doi.org/10.1002/esp.3440

Chalikakis K., Plagnes V., Guerin R., Valois R. \& Bosch F.P., 2011 - Contribution of geophysical methods to karst-system exploration: an overview. Hydrogeology Journal, 19 (6): 1169-1180.

http://dx.doi.org/10.1007/s10040-011-0746-x

Chamberlain A.T., Sellers W., Proctor C. \& Coard R., 2000 - Cave detection in limestone using Ground Penetrating Radar. Journal of Archaeological Science, 27: 957-964.

http://dx.doi.org/10.1006/jasc.1999.0525

Čekada M., Gostinčar P. \& Staut M., 2011 - Speleological map of the Kanin massif, Caves in the Kanin massif sheet, 1: 10.000. Slovenian Speleological Society, Ljubljana, $31 \mathrm{p}$.

Daniels D.J., 2004 - Ground Penetrating Radar. The Institution for Electrical Engineers, London, $726 \mathrm{p}$. http://dx.doi.org/10.1049/PBRA015E

Davis J.L. \& Annan A.P., 1989 - Ground-Penetrating radar for high-resolution mapping of soil and rock stratigraphy. Geophysical Prospecting, 37 (5): 531-551. http://dx.doi.org/10.1111/j.1365-2478.1989.tb02221.x

De Giorgi L. \& Leucci G., 2014 - Detection of hazardous cavities below a road using combined geophysical methods. Surveys in Geophysics, 35: 1003-1021. http://dx.doi.org/10.1007/s10712-013-9277-4

Delle Rose M. \& Leucci G., 2010 - Towards an integrated approach for characterization of sinkhole hazards in urban environments: the unstable coastal site of Casalabate, Lecce, Italy. Journal of Geophysics and Engineering, 7: 143-154.

http://dx.doi.org/10.1088/1742-2132/7/2/004

El-Qady G., Hafes M., Abdalla M.A. \& Ushijima K., 2005 - Imaging subsurface cavities using geoelectric tomography and ground-penetrating radar. Journal of Cave and Karst Studies, 67: 174-181.

Frumkin A., Ezersky M., Al-Zoubi A., Akkawi E. \& Abueladas A.R., 2011 - The Dead Sea sinkhole hazard: Geophysical assessment of salt dissolution and collapse. Engineering Geology, 134: 102-117. http://dx.doi.org/10.1016/j.geomorph.2011.04.023

Gabrovšek F. \& Otoničar B., 2010 - Kras na Kaninskih podih. In: Košir A. (Eds.), Proceedings of the $3^{\text {rd }}$ Slovenian Geological Congress, Bovec, ZRC-SAZU, Ljubljana, 99-106.

Gómez-Ortiz D. \& Martín-Crespo T., 2012 - Assessing the risk of subsidence of a sinkhole collapse using ground penetrating radar and electrical resistivity tomography. Engineering Geology, 149-150: 1-12.

http://dx.doi.org/10.1016/j.enggeo.2012.07.022

Gosar A., 2012 - Analysis of the capabilities of low frequency ground penetrating radar for cavities detection in rough terrain conditions: The case of Divača cave, Slovenia. Acta Carsologica, 41: 77-88.

Jol H.M., 2009 - Ground Penetratig Radar: Theory and applications. Elsevier, Amsterdam, $544 \mathrm{p}$.

Kunaver J., Celarc B., Dakskobler I., Ivančič I., Klavora V., Mihelič M., Pirnat J., Trilar T. \& Belingar M., 2011 Kaninsko pogorje: naravoslovni, zgodovinski in turistični vodnik. Turistično društvo Bovec, Bovec, 167 p.
Leucci G. \& De Giorgi L., 2005 - Integrated geophysical surveys to assess the structural conditions of a karstic cave of archaeological importance. Natural Hazards and Earth System Science, 5 (1): 17-22.

http://dx.doi.org/10.5194/nhess-5-17-2005

Leucci G. \& Negri S., 2006 - Use of ground penetrating radar to map subsurface archaeological features in an urban area. Journal of Archaeological Science, 33 (4): 502-512. http://dx.doi.org/10.1016/j.jas.2005.09.006

Mala, 2010: ProEx - Professional Explorer control unit, Operating manual. Mala, 60 p.

Martinez-Moreno F.J., Pedrera A., Ruano P., GalindoZaldivar J., Martos-Rosillo S., González-Castillo L., Sánchez-Úbeda J.P. \& Marín-Lechado C., 2013 Combined microgravity, electrical resistivity tomography and induced polarization to detect deeply buried caves: Algaidilla cave (Southern Spain). Engineering Geology, 162: 67-78.

http://dx.doi.org/10.1016/j.enggeo.2013.05.008

McMechan G.A., Loucks R.G., Zeng X. \& Mescher P., 1998 - Ground Penetrating Radar imaging of a collapsed paleocave system in the Ellenburber dolomite, central Texas. Journal of Applied Geophysics, 39: 1-10. http://dx.doi.org/10.1016/S0926-9851(98)00004-4

Mochales T., Casas A.M., Pueyo E.L., Pueyo O., Roman M.T., Pocovi A., Soriano M.A. \& Anson D., 2008 Detection of underground cavities by combining gravity, magnetic and ground penetrating radar surveys: a case study from Zaragoza area, NE Spain. Environmental Geology, 53: 1067-1077.

http://dx.doi.org/10.1007/s00254-007-0733-7

Murphy P., Westerman A.R., Clark R., Booth A. \& Parr A., 2008 - Enhancing understanding of breakdown and collapse in the Yorkshire Dales using ground penetrating radar on cave sediments. Engineering Geology, 99: 160-168.

http://dx.doi.org/10.1016/j.enggeo.2007.11.015

Pirnat J., 2002 - Jamarstvo na Kaninu. In: Kunaver J., Bracic L. \& Avsenik Nabergoj I. (Eds.) Soški razgovori I : zbornik za domoznanstvo zgodovinske sekcije KD Golobar. KD Golobar, Bovec, 77-98.

Piscitelli S., Rizzo E., Cristallo F., Lapenna V., Crocco L., Persico R. \& Soldovieri F., 2007 - GPR and microwave tomography for detecting shallow cavities in the historical area of "Sassi of Matera" (Southern Italy). Near Surface Geophysics, 5 (4): 275-84. http://dx.doi.org/10.3997/1873-0604.2007009

Pueyo-Anchuela O., Pocovi-Juan A., Soriano M.A. \& Casas-Sainz A.M., 2009a - Characterization of karst hazards from the perspective of the doline triangle using GPR -Examples from Central Ebro Basin (Spain). Engineering Geology, 108: 225-236. http://dx.doi.org/10.1016/j.enggeo.2009.06.022

Pueyo-Anchuela O., Casas-Sainz A.M., Soriano M.A. \& Pocovi-Juan A., 2009b - Mapping subsurface karst features with GPR: results and limitations. Environmental Geology, 58 (2): 391-399. http://dx.doi.org/10.1007/s00254-008-1603-7

Pueyo-Anchuela O., Casas-Sainz A.M., Pocovi-Juan A. \& Gil-Garbí H., 2015 - Assessing karst hazards in urbanized areas. Case study and methodological considerations in the mantle karst from Zaragoza city (NE Spain). Engineering Geology, 184: 29-42. http://dx.doi.org/10.1016/j.enggeo.2014.10.025

Reynolds J.M., 2011 - An introduction to applied and environmental geophysics. Wiley, New York, 710 p.

Seren A., Babacan A.E., Gelisli K., Ogretmen Z. \& Kandemir R., 2012 - An investigation for potential extensions of the Karaca Cavern using geophysical methods. Carbonates and Evaporites, 27: 321-329. http://dx.doi.org/10.1007/s13146-012-0115-4 
Sharma P.V., 1997 - Environmental and engineering geophysics. Cambridge University Press, Cambridge, 475 p.

http://dx.doi.org/10.1017/CBO9781139171168

Vadillo I., Benavente J., Neukum C., Grützner C., Carrasco F., Azzam R., Liñán C. \& Reicherter K., 2012 - Surface geophysics and borehole inspection as an aid to characterizing karst voids and vadose ventilation patterns (Nerja research site, S. Spain). Journal of Applied Geophysics, 82: 153-162.

http://dx.doi.org/10.1016/j.jappgeo.2012.03.006
Zajc M., Pogačnik Ž. \& Gosar A., 2014-Ground Penetrating Radar and structural geological mapping investigation of karst and tectonic features in flyschoid rocks as geological hazard for exploitation. International Journal of Rock Mechanics and Mining Sciences, 67: 78-87. http://dx.doi.org/10.1016/j.ijrmms.2014.01.011

Zajc M., Celarc B. \& Gosar A., 2015 - Structural-geological and karst feature investigations in the limestoneflysch thrust-fault contact using low-frequency ground penetrating radar (Adria-Dinarides thrust zone, SW Slovenia. Environmental Earth Sciences, 73 (12): $8237-$ 8249. http://dx.doi.org/10.1007/s12665-014-3987-x 